\title{
Analysis of the Semantic Scope of Two Korean Terms Equivalent to English Court
}

\author{
Emilia Wojtasik-Dziekan ${ }^{1}$ (D)
}

Published online: 10 March 2020

(c) The Author(s) 2020

\begin{abstract}
The article aims to analyze the semantic fields of two Korean terms in the field of a specialized judicial terminology, i.e. court and tribunal, which are usually reflected in English by one hypernym term court. This analysis, although carried out on limited Korean data, is intended to indicate the differences between the use of these two different Korean terms and to indicate the reasons why court is currently the most common English equivalent. At the same time, the author, by pointing to the historical and cultural background, explains the reasons why the term court is not always correct. The methods used in compiling the data are to highlight differences in the semantics of Korean terms covered by an English hypernym court.
\end{abstract}

Keywords Semantics $\cdot$ Korean language $\cdot$ Korean legal translation $\cdot$ Korean language of law $\cdot$ Court $\cdot$ Tribunal

\section{Introduction}

In in-depth translation studies it is impossible not to refer to potential differences between given terms. These differences, in turn, are analyzed in many different ways in order to, starting from the semantic field (cf. e.g. [1, 2]), be able to choose contextually the best possible term, which, despite being taken as a synonym, does not have to be the full one. As a method, an analytical approach to the semantic field of a given word, as suggested by Zajda [3], allows "to analyze vocabulary comprehensively within smaller structures" and at the same time.

to trace the history of fields and within them words - components of the structure over many centuries and show the fascinating history of vocabulary - a

Emilia Wojtasik-Dziekan

ewojtasik@yahoo.com; emilia.w@amu.edu.pl

1 Faculty of Modern Languages and Literature, Adam Mickiewicz University, Collegium Novum, Room No. 319 B, al. Niepodległości 4, 61-874 Poznań, Poland 
language subsystem which is a mirror reflection of the nation's life, culture, and various contacts with the outside world. ${ }^{1}$

If the significance of the semantic field is also taken into account in determining the ground for a given term and its synonymy or polysemy, etc. (confer e.g. [4]), it will turn out that in in-depth lexical studies it should be the starting point. This research approach can also be applied in the case of the Korean lexicon, although it seems that the diversity and history of creating the Korean lexicon should be particularly taken into account. Korean language is a place-field where not only historically the linguistic influences of other countries, i.e. China (to a much greater extent) and Japan (much less) were clustered but also a field where it is difficult to clearly define the nature of borrowings (cf. [5-7] etc.).

Therefore a special attention in the field of semantic fields should be devoted to a specialized terminology, as on the basis of the field it is possible to clarify a scope of a term and thus facilitate the decision-making on which further language decisions in the field of communication will be based. For these reasons, this article will be entirely devoted to the analysis of two Korean terms 법원 beobweon and 재판 소 jaepanso, which are currently most often translated ultimately into English as court, yet only one of them is actually fully equivalent. Therefore, in the beginning of the text both terms will be used altogether, e.g. court/tribunal. According to the author, however, the semantic field and historical background indicate significant differences that will be crucial for the researcher in order to choose which court is a court and which one is actually a tribunal. In the case of the Korean, the analysis should be based first of all on Chinese ideograms, which form the basis for legal terminology and for the language of law.

The research methods used in this article include semantic analysis of the field of Korean words court and tribunal. The scope that was subject to analysis include only the names of individual courts and tribunals in order to demonstrate the legitimacy of using one or the other term with deliberate resignation from collocation analysis.

The research corpus for the conducted research included the resources available online on the National Law Information Center website, with particular emphasis on sets of statutes and ordinances, where the titles of those (for term court $_{1} 482$ legal acts and for term court $_{2} 1588$ acts) were analyzed on the material concerning South Korea. The South Korean Court Organizational Acts (of 25th March, 1895 and of 15th July, 1949) and the Democratic People's Republic of Korea Constitution (part on courts) were also examined. The Court Organizational Act has been analysed as it contains the legal information on the modern judicial structure, therefore, this section also examines the phrases determining the type of court. North Korean legal material was limited due to low availability. Lexicographic resources of Korean dictionaries of legal terminology were also used.

\footnotetext{
1 Polish quotation for Zajda [3], pp. 10-11: ,analizować słownictwo kompleksowo w ramach mniejszych struktur”, ,prześledzić historię pól, a wewnątrz nich wyrazów—składników struktury na przestrzeni wielu wieków i ukazać frapujące dzieje słownictwa-subsystemu językowego, będącego zwierciadlanym odbiciem życia narodu, jego kultury, różnorodnych kontaktów ze światem zewnętrznym”. English translation by the Author.
} 
All Korean terms will be also given a transcription in line with the principles of Revised Romanisation of Korean Language 국어의 로마자 표기법 國語의 로 마의 表記法 Gugeo-ui romaja pyogi-beob [8] introduced in July 2000 by the Ministry of Culture and Tourism of South Korea. For a better understanding of semantic complexities, Chinese ideograms will be given for borrowings where necessary. In order to help along with the assimilation of Chinese ideograms content in sections no. 1, 2 and partially 3, the following abbreviations have been introduced: Chin. for Chinese characters, Kor. for Korean notation of the syllable.

\section{The Influence of the Chinese Language and Writing on the Development of the Korean Language Over the Centuries}

It is a truism to emphasize the historical influence of Chinese culture on Korean culture since it was a continuous process during the period of Korean statehood. The impact of Mongolian (cf. [5]) or Japanese (cf. [9]) culture was also observed, and additionally Russian and American in the twentieth century. However, when speaking of the Korean language, it is impossible not to mention the direct and indirect influence of the Chinese language ${ }^{2}$ associated with the political history of China. This influence became apparent in varying degrees in the written and spoken language, which in turn was important for its (in)formality and (un)officiality.

Lee and Ramsey ([10], pp. 34-36) emphasize that on the Korean Peninsula existed and intermingled such languages as Buyeo (Kor. 부여어 buyeo-eo, Chin. 夫餘語) languages which were slightly different from each other and under strong influence of the Chinese language, and much more linguistically distant Han languages (Kor. 삼한 'Three Han' samhan, Chin. 三 韓). The strongest of the Buyeo languages proved to be the Goguryeo language (Kor. 고구려어 goguryeo-eo, Chin. 高句麗語), which functioned on the northern part of the Peninsula for almost seven centuries. On the other hand, Han languages existed in that time respectively in Baekje (Kor. 백제, Chin. 百 濟), Silla (Kor. 신라, Chin. 新 羅) and Gaya (Kor. 가야, Chin. 加 倻). Migration of population and geopolitical realities of this part of the world caused that the influence of Chinese and China strengthened on the Peninsula, leading to many changes in the law and the language it used. The period of existence of the parallel Korean Three Kingdoms ${ }^{3}$ (Goguryeo, Baekje and Silla, which annexed the kingdom of Gaya later on) was the period of adoption of Chinese administrative and criminal law, Confucian education, judicial structures, etc., which in turn resulted in further changes in the late United Silla's period (Kor. 통 일 신라 Tongil Silla, Chin. 統一 新 羅; up to 935) and Goryeo (Kor. 고려, Chin. 高 麗; until 1392) and further countries (cf. [11]). Political changes caused language changes within the official language, leading to the spread of the presence of Chinese in the lives of Koreans. Lee and Ramsey [6], p. 46 emphasize that:

\footnotetext{
2 The author uses the parent term 'Chinese' for all Chinese languages.

${ }^{3}$ Here we are talking about the period of the first century BC.- - VII century AD.
} 
From the beginning, knowledge of Chinese characters seems to have had two functions in Korea. One was to accommodate and read works written in Literary Chinese, and, at the same time, to write narratives and keep records in that language. The other was to write down Korean.

The importance of Chinese for the development of the Korean language is enormous. All people who were well-born, prosperous, successful or willing to succeed were required to have fluent command of the classical Chinese called hanmun (Kor. 한문, Chin. 漢文). Chinese was the language in which literature was written, students were taught, the law was codified and legal documents were created. It was also used to record the Korean language at that time. Paradoxically, it also became an incentive to start work on creating the Korean alphabet (cf. [12]). However, before the work on the alphabet began, it functioned in the literary reality created by the Chinese language. Koreans have attempted, more or less successfully, to adapt the difficult writing to the language capabilities of that time, creating in turn the systems of gugyeol (Kor. 구결, Chin. 口訣), Hyangchal (Kor. 향찰, Chin. 鄉 札) and idu (Kor. 이두, Chin. 吏 讀/吏 頭 ${ }^{4}$ ). The gugyeol system operated at the word level of the Chinese language along with Chinese pattern and Korean grammar as well as semantic exponents at the level complementing the grammar elements, auxiliary verbs, adjective and verb suffixes, numerals, punctuation, written using the most similar meaning of Chinese characters (cf. [5], p. 127). It was an approach involving the combination of classical Chinese with Korean language elements, so "if the kugyŏl characters were removed, the text written in the Chinese literary language would remain"s ([14], p. 255).

In the later period (i.e. after the release of the alphabet), the characters carrying grammatical information were replaced by the Korean writing system. The second system, called hyangchal, was mainly used in broadly understood poetry. It functioned for a rather short period of time, only for three centuries-it was discontinued after the Goryeo dynasty took power (around the tenth century AD; cf. [12], pp. 157-211). The third system based on Chinese was the idu system, considered as a functioning official style, which was justified in the light of the policy of close contacts with China at the time. Idu used Chinese characters and elements of the Korean grammar expressed in characters. However, the language already maintained the Korean sentence (S-O-V) pattern (cf. [6], pp. 53-55). The gugyeol and idu systems, based on Chinese, were regarded as official ones. These systems were used by lower-level officials to create legal documents, all kinds of receipts, etc. (cf. [15], pp. 69-70), which meant that most of the Korean society also had to adapt to these systems. It also meant that legal practice existed in the world of the Chinese language, influencing the language of Korean law at that time. The development of the Korean Hangeul alphabet in 1443 was a milestone in the development of Korea in general. However, the official recognition of the alphabet as a linguistic means of transmitting legal information was not until the year of Gabo Reforms (Kor. 갑오 개혁 Gab-o gaehyeog; Chin. 甲午 改革) ${ }^{6}$ in 1894, which resulted in a number of legal changes.

\footnotetext{
${ }^{4}$ In the Korean lexicography there is an alternative way of writing the second character. See: [13].

5 "gdyby usunąć znaki kugyŏl, pozostałby tekst napisany chińskim językiem literackim". English translation done by the Author.

${ }^{6}$ The older name is Gabo Gyeonjang 갑오 경장, Chin. 甲午 更 張.
} 
Oh [15], p. 70 emphasizes that it was King Gojong's decree (Kor. 고종, Chin. 高 宗) of 1894 which ordered the use of the alphabet as the sole means of recording documents, and published a year later it also included mixed-type entries (Korean alphabet and Chinese characters).

The period of Korea's annexation by Japan meant that the language of the Korean law at the time was adapted to the Japanese terminology. At that time, a wave of changes was observed in the area of law, language of law and Korean in general. The Korean law was adapted to Japanese legislation, which in turn meant the introduction of elements of Western law, especially German, into the current Korean law modeled on the Chinese pattern (cf [16], p. 5). It also meant a return to a mixed writing system.

The period of such practice ended formally on October 9, 1948, when 한글 전용 에 관한 법률 Hangeul jeonyong-e gwanhan beobryul, the Act on the Official Use of the Korean Language [17] was adopted for documents and legal acts arising from that day, allowing the use of Chinese characters for the period necessary to make changes. This process proceeded gradually but effectively.

\section{Courts and Judiciary in Korea Over the Centuries}

The neighborhood and relations with China had more than just linguistic effects. The Chinese influence over Korean also became apparent in the legislation, which in turn created the reality of the Korean executive, legislative and judicial authorities.

As the article focuses on the judiciary, this subsection will refer only to the most important stages in its development, bypassing the other types of power and the development of law with its branches. The period of the Three Kingdoms (Kor. 삼 국 시대 samgug sidae, Chin. 三國時代) was a time when judicial power was concentrated mainly in the hands of the rulers of the clans or the council of clan elders at that time. Kim Kipyo [16], p. 3 even writes that in Goguryeo "The Kingdom [...] had a conference of tribal leaders serving as the top judicial organization". In Baekje power was wielded by a minister appointed by the king, and in Silla court cases were handled by high-level administrative officials (cf. [12]). The reign of the Goryeo dynasty was modeled on the rights established by the Chinese Song dynasty. King Wang Geon (Kor. 왕건, Chin. 王建) established the institution acting as the central court called Uihyeongdae (Kor. 의형대, Chin. 義 刑 臺). It dealt with court (criminal and civil) cases and other matters of a legal nature under its jurisdiction. Kim Kipyo [16], p. 3 points out that "at the end of its history, local administrators who ruled its own territories by armed forces, began taking up judicial functions". There was a division of jurisdiction-matters related to the capital were subordinated to the main official acting as mayor, and what concerned the rest of the country was decided by officials holding the highest administrative position in a given area. The appellate judges were the royal emissaries or province governors.

The legal system in the period of Joseon (Kor. 조선, Chin. 朝鮮) was included in the Code of Governance of the Country (Kor. 경국 대전 gyeonggug daejon, Chin. 京畿 戰爭), which was supplemented by the Code of Great Mings (Kor. 대명률 daemyoeng-ryul, Chin. 大明律). Minor cases (civil and criminal) were subject to 
local administration, the governor of each province resolved appeals against judgments and decisions of first degree courts or in more serious criminal cases. There were also secret royal inspectors called Amhaeng-eosa (Kor. 암행 어사, Chin. 暗 行御史) who served the special functions of the district judges. An appeal against a governor's judgment or decision was brought to the Minister of Justice at the central level called Hyeongjo (Kor. 형조, Chin. 刑曹). There were many institutions dealing with various types of cases depending on the origin of the plaintiff or accused person (cf. [16], p. 4). In the period of Joseon kingdom, the administration and the judiciary were not separated, and the king wielded all kinds of power. The court actually existed at the level of government administration and the local officials acted only within their jurisdiction. Hence, it can be concluded that the judiciary enjoyed great esteem and reputation at that time.

The Gabo reforms led to the separation of the judiciary and government administration. On December 12, 1894 a new law called 14 Principles of Legal Standards (Kor. 홍범14조 hongbeom-14-jo, Chin. 洪範十四條) was adopted by the King Gojong. Less than half a year later (March 25, 1895) the act on the structure of courts, which became the basis for later changes, was adopted (Kor. 재판소구성법 jaepanso guseong-beob, Chin. 裁判所構成法).

\section{The Term court $_{1}$ : 재판소 裁判所 jaepanso}

The semantic analysis, focusing on particular characters and the meaning of ideograms, especially underlines the potential synonymy of this term. The ideogram 裁 (Chin. cái, Kor. 재 jae) means in total, to put it simply, 'to take a decision'—결단 하다 gyeoldan-hada, 'to make a differentiation'一분별하다 bunbyeol-hada, which evolved to mean 'to resolve'. The character 判 (Chin. pàn, Kor. 판pan) is in turn fully associated with the verb 판단하다 pandan-hada -'assessment, deciding what is true'. The last ideogram, 所 (Chin. suǒ, Kor. 소 so) means 'a place'. This last element is attached to underline the spatial scope of the term. Two first ideograms mean together 'to decide about the truth', and all three collectively - 'a place of taking such a decision'. On the basis of this analysis it can be found that this term means a 'court', and, to be more precise, 'a place of giving an opinion in the court proceedings'. This assumption could be also corroborated by the dictionary term which underlines that it is a term not only belonging to the legalese and the language of the law but also that it means directly 'the body taking decisions and settling arguments and disputes', with the synonymous term beobweon 법 원 法院 [18].

The term 재판소 裁判所 jaepanso is consequently the term translated into the hypernym court. However, in case of this term it should be noted that is appears only in certain phrases, constituting simultaneously the description of the types of courts of special purpose. At present this noun forms only a few names, underlining the exceptional character of a given judicial body.

This limitation in use is connected not only with the customary and phraseological scope. Although colloquially 재판소 裁判所 jaepanso is synonymous with 
other terms of court as a body and although it forms a few specific names of Korean judicial institutions, its history and etymology is a bit more complex.

Although this term, written in Korean, has Chinese origins, which is documented by possible double way of writing, i.e. with the use of Chinese characters, ${ }^{7}$ this borrowing did not appear in the Korean legal language by way of direct terminological transfer from China. Despite the fact that the Korean legal language to a significant extent is dominated by the terminology with Chinese origin, numerous terms appeared as a result of secondary borrowings through Japan. No matter what the present approach to the terminology with Chinese origins is, it is incorporated into the lexis of the Korean language (confer [6] p. 125; 135) to such a significant extent that the Korean specialist legalese and the language of law barely use other phrases based on the native terminology and use those rooted in the language and segment of the legal reality.

Therefore, in case of 재판소 裁判所jaepanso, not only the semantic scope but also history should be taken into account.

The historic analysis of the evolution of 재판소 裁判所 jaepanso in the Korean language shows however significant systemic and usage limitations. The term itself as a description of the judicial body appeared in the Korean language almost at the end of nineteenth century, in line with turbulent political changes resulting also in structural reforms of the administration and law. This was caused by the fact that the pro-reform group 개화파 gaehwapa, gained power in 1894 and in the next subsequent years conducted a series of reforms, involving also the judiciary and administration. ${ }^{8}$

So far the appellate cases were entrusted to 의금사 義禁司 uigeum-sa, ${ }^{9}$ however, as a result of the reform and re-implementation of this institution in the Justice

\footnotetext{
${ }^{7}$ An example of such changes in the law, leading to simplification of the difficult legalese and law language, as well as ordering and unification of notation is a number of acts regarding the Korean language in general (e.g. Act on correct spelling and rules of standardization 국어 기본법 gugeo gibon-beob from 2001, last amended September 22, 2017 [19] or already mentioned Act on Revised Romanization of 2000국어의 로마자 표기법 gugeo-ui romaja pyogi-beob) [8] and the language of Korean law in particular (e.g. Draft act on taking special measures to correlate the language of law of December 29, 2004 법률 한글화 위한 특별 조치 법안 beobryul hangeulhwa wihan teugbyeol-jochi-beoban) [20]. Admittedly, the acts assume that these simplifications are to consist in, inter alia, mainly on creating citizenfriendly law and its notation in the Korean alphabet without references to ideograms, but they also contain conclusions that if the use of ideograms allows for greater readability and a comprehension of the text, their use is allowed.

${ }^{8}$ The pro-reform group gaehwapa opposed the traditional Confucian and monarchy system, striving for reformation of all the possible areas which previously were influenced by the Chinese legislation. Eight ministerial units were created, including the then Justice Ministry 법무아문 法務衙門 beobmu amun, settling also legal and administrative issues. As Kim [16], p. 5 states, "The separation of judicial operations from the government administration was recognized as a major step towards the formulation of the modern legal system".

${ }^{9}$ Before it was named 의금사 義禁司 uigeumsa this institution's name was very similar to 의금부 義 禁府 uigeumbu. It was not only the shift of the meaning of the name (the last segment $s a$ replaced $b u$, lexically replacing the structural element [office, department] with the element [governmental office]), it was also the change involving modifications in the scope of duties. The new unit replaced a historically renown governmental office, regulated by and hearing appeals on behalf of the king, it also became a part of the Justice Ministry. The Minister automatically received the title of Justice Office Judge 의금부 판사 uigeum-bu pansa. It consisted of the Minister and four inspectors. Confer [21].
} 
Ministry and as the Japaneses legislation laid the foundations for the subsequent law reform which took place after Donghak revolution in 1894, and as post-revolution cases were still pending, this unit was converted into 법무아문권설재판소 法務 语門勸說裁判所 beobmuamun-gweonseol-jaepanso, which can be translated as Justice Ministry Tribunal/Court. All the cases which had been heard by the Ministry before this happened were referred to this new judiciary unit (confer [21], pp. 153-158). Historians unanimously underline that this was the first noted use of 재 판소 裁判所 jaepanso [22]. The historical environment (Donghak revolution, Gabo reforms, etc.) allows us to notice the exceptional character of its incorporation into the register of specialist terminology connected with lying the foundations of the twentieth-century Korean legislation.

The next application of this term takes place in the Act on Court/Tribunal Structure $^{10}$ 재판소 구성법 jaepanso guseong beob, which was adopted on 25 March 1895 and which introduced five main types of courts and defined their instance principles. It can be assumed that in the light of the terminology of the then legislation this term referred more to a court than tribunal, although still to the 'place of giving judicial opinion and decisions'. This Act was binding till 28 October 1909.

In 1949 the previous Act on Court/Tribunal Structure 재판소 구성법 jaepanso guseong-beob was replaced with the act whose title already includes the term 법 원 beobweon replacing the earlier term jaepanso. That act was the Court Organization Act 법원조직법 beobweon-jojig-beob of 15.08.1949, in force on 26.09.1949 [23]. It is an important time frame as it coincides with significant changes in the political system in the Peninsula. In 1948 in lieu of one state freed from Japanese occupation two states were formed with different political systems-the Republic of Korea (15.08.1948) colloquially named the South Korea and the Democratic People's Republic of Korea (9.09.1948), colloquially named the North Korea ([12], pp. 354-357). Those states developed in different directions, which was also reflected in the language of law.

\subsection{South Korea}

The analysis of the available archives of the laws allows to observe a gradual shift in using the term jaepanso till its use became restricted to a few specifically defined situations. Those circumstances concern the South Korean language of law in which in the last 70 years, i.e. from the moment the Republic was formed, the term jaepanso was presumably used only to underline the uniqueness and separateness of the body.

Now, as quoted by the National Law Information Center, ${ }^{11}$ this term ${ }^{12}$ is incorporated in 16 names of laws and regulations. Deepened search of the legal act database available at National Law Information Center website resulted in finding

\footnotetext{
${ }^{10}$ The parallel usage of these two terms in this place is intentional.

${ }^{11}$ As the search for the term on the website National Law Information Center 국자법령정보센터 [24] shows. Accessed 9.09.2019.

12 The occurrence of the first segment of this term, i.e. 재판 jaepan, corresponding to a court hearing was not analysed.
} 
482 cases when the word 재판소 jaepanso was used in the name of the legal act. Rejection of other elements of titles of particular legal acts, which were used only for better precision, allows us to observe that in total there are only ten (the first seven only according to the Dictionary, the subsequent 3 complement the dictionary data under the data from the legal act database) cases of using the term 재판 소 jaepanso as an element of a name, allowing for determination of the institution specificity:

1. 헌법재판소 憲法裁判所 heonbeob jaepanso

2. 국제해양법 재판소 國際海洋法裁判所 gugje haeyangbeob jaepanso

3. 국제사법재판소 國際司法裁判所 gugje sabeob jaepanso

4. 국제연합행정재판소 國際聯合行政裁判所 gugje yeonhap haengjeong jaepanso

5. 국제형사재판소國際刑事裁判所 gugje hyeongsa jaepanso

6. 탄핵재판소 彈核裁判所 tanhaeg jaepanso

7. 행정재판소 行政裁判所 haengjeong jaepanso

8. 조선총독부재판소 朝鮮「督府裁判所 joseon chongdogbu jaepanso

9. 특별재판소 特別裁判所 teugbyeol jaepanso

10. 혁명재판소 革命裁判所 hyeogmyeong jaepanso

The term no. 1 defines at present the most supreme judicial institution in South Korea. The official translation of the name of this institution into English is Constitutional Court of Korea [25]. Term no. 2 is the Korean translation of the name of the international institution-International Tribunal of the Maritime Law [26]. Term no. 3 is also the Korean translation of the international name of the institutionInternational Justice Tribunal/International Court of Justice [27]. Term no. 4 is the Korean translation of the name of the international institution-Administrative Tribunal of the United Nations. Term no. 5 is the Korean translation of the international name of the institution-International Criminal Justice Tribunal. Term no. 6 is the Korean name of the archaic court institution from the period of the 1st and 2nd Republic of Korea [28], abolished by the law of 1961 [28] before introduction of the military regime. It refers as a result to a non-existent institution and shows strictly historic connotation. One may regard this as institutional translation into the State Tribunal. Term no. 7 is a dictionary term [29], which could be an equivalent of the Supreme Court of Justice and which was quickly replaced by a term more adequate for the changing Korean legislation and the Korean language of the administrative law. Term no. 8 refers only to the judiciary period during the Japanese occupation of 1910-1945 and is translated as General Governorate Court/Tribunal. Also in this case this name noticeably became archaic. This institution was abolished at the end of occupation but the analysis of the legal acts allows for determination that the process of abolishing old legal acts connected with this body lasted till 1962. Term no. 9 names a historic institution which existed in the South Korea very briefly, barely a year: 1960-1961 [30], so in the period of political destabilisation. Term no. 10 is the last one, it refers to the name of the body following the institution mentioned in Term no. 9. It came into existence in August 1961 after the coup d' etat on 16 May, 
1961 [31] and was the equivalent of Revolutionary Tribunal. As a result of coup d' etat and takeover of power by the military, South Korea was ruled in this period by a dictator, and the state of emergency lasted till the end of 1962 ([12], p. 375).

In the 10 names mentioned above, as many as four of them include the term jaepanso in the context of international institutions, the subsequent four refer to an archaic and abolished institution. Only two national units have their place in the contemporary legislation of South Korea and actively function there.

\subsection{North Korea}

Apart from South Korean legislation we should also analyse the names of the North Korean courts with the use of the term jaepanso. Bearing in mind that as a country North Korea was officially formed in 1948 and the North Korean language differs from the South Korean, analysing the court system defined by the Constitution of the Democratic People's Republic of Korea [32] it may be observed that ${ }^{13}$ at present the term jaepanso is incorporated in the name of only five institutions:

\section{1. 최고재판소 最高裁判所 chwigojaepanso \\ 2. 중앙재판소 中央裁判所 jungangjaepanso \\ 3. 도(직할시) 재판소 道(直轄市)裁判所 do (jighalsi) jaepanso \\ 4. 인민재판소 人民裁判所 inmin jaepanso \\ 5. 특별재판소 特別裁判所 teugbyeol jaepanso}

Contrary to specific South Korean institutions, four of the said North Korean institutions still function. The first and second term is basically an element of the name for the same institution. The change has taken place relatively recently and is connected with the amendments to the Korean law. They were used interchangeably, i.e. in 1948 the first term was used, and since 1972 it was changed into the second one, in 2010 the first term came back into use, and since 2016 the second term has been used. Irrespective of slight jurisdictional shifts, the first and second term correspond to Supreme Court of North Korea or The Central Court. Both names incorporate the element jaepanso, both also are based on the first segment of the name underlining the supremacy over the other types of judicial institutions (최고 chwigo means 'supreme', 중앙 jungang means 'central, main'). The third term contains extension referring to an old Korean term, no longer functioning in the South Korean language, meaning 'metropolitan city'. In this case we should analyse the first morpheme which indicates that it is also a court at a provincial level. Term no. 4 containing the element 인민inmin 'people's' in its name determines the court of the lowest instance and despite the element indicating the relation with the political

\footnotetext{
13 In this paper the author skipped the historical development of the court system, i.e. from the moment Democratic People's Republic of Korea was formed, due to the fact that in the light of the presently applicable law and the fact that the term appears in currently functioning names, particular changes of the scope of jurisdiction are not significant for determination of the meaning and semantic scope of the term. About the development of the North Korean court system see e.g. [33].
} 
system, it may refer to a district court, called People's Courts or Court of the Country. Terms 3 and 4 constitute in principle names of the courts of lower level and indicate their instance (accordingly the first one-higher, the second one-lower). The last name, due to the 'exceptional, special' element—특별—is equivalent to 'court of special purpose' and includes inter alia martial courts (confer [34]).

Generally speaking, the language of North Korean law did not undergo such turbulent changes as the South Korean one. This does not apply to the rest of the lexicon, which has actually changed significantly and the direction of these changes is different from the direction of the South Korean lexicon. ${ }^{14}$ What is more, a clear tendency can be seen in the language of law to stick to the old lexicon and stay away from the influence of the so-called western languages, despite dynamic movement in the contemporary variable geopolitical environment of North Korea. ${ }^{15}$

\section{The Term court $_{2}$}

The second term which is translated as court, involves the Korean term법원 beobweon. It also has Chinese origins but in this case, apart from potential synonymy with the term jaepanso, we should also pay attention to heterographic writing of the characters. It appears that the term beobwon may be ideogramically written in two ways (and functions like this in dictionaries of legalese and the language of law): 法院 and 法源. Characters located at the bottom result in the fact that the meaning of this word, homophonic and homographic in the alphabetical spelling, will vary depending on the ideogram writing.

The first term, 법원 法院 beobweon, in accordance with the explanation given by the Korean Language Dictionary [36] refers to the state institution functioning in the judicial power and a given organizational structure. It is compliant with the ideograms forming the word-the first one, 法 Chin. fă, Kor. 법 beob means 'law', the second one-院 Chin. yuàn, Kor. 원 weon, means 'house'. By inference, the simplest, descriptive explanation will mean 'a house of the law' so an institution wielding and administering law. The dictionary also suggests that the previously described term jaepanso is synonymous with the work, which indicates the ground for comparison. We may consequently assume that the first term is in fact closer to court.

The second term 법원 法源 beobweon unveils its meaning and diversity thanks to the second character. The first one (法 Chin. fă, Kor. 법beob), meaning 'law' is common and underlines the relation with the field of law, however, the second one transfers the meaning into completely another area. Ideogram 源 Chin. yuán, Kor. 원 weon means 'basis, source'. In this case the total meaning will not be convergent

\footnotetext{
14 Yoon Jaehoon [35], p. 181, writes more about the specifics of the North Korean lexicon: "Abolition of many Sino-Korean words, standardisation of words originating from northern dialects and archaic words, or coining of new words during the so-called Mal tatumki wuntong (Language purification movement) have resulted in vocabulary divergence between the North and the South.".

15 The author means inter alia opening to West during the reign of Kim Jeong-Eun 김정은, warming up of the relation with South Korea and simultaneous continuance of ballistic missile tests etc.
} 
with the homophonic first beobweon as it will mean 'source of law' so legislation as the source of legal acts which may be or form the foundations for a given law [37]. The same is indicated in the Legal Terminology Dictionary which expands the explanation of the term to include its context amplification. Thus, beobweon is an abbreviation of 법의 연원 法의 淵源 beob-ui yeonweon, namely 'beginnings of law' [38]. In this case the homophone beobweon without the ideogramic background can only be distinguished thanks to the context and embedding in a bigger text unit and not analysing it in isolation.

The analysis, conducted in a way analogous to the term jaepanso, of the search results concerning the legal acts and the Dictionary of Legal Terminology provided more extensive results than before. The dictionary of terms gives 8 results [39], the dictionary of legal definitions - as many as 50 [40], while the total search in the base of legal acts without dividing them into categories depending on their nature i.e. regulation, promulgation, administrative decisions - as many as 1.588 results. $^{16}$

A detailed analysis of the collective search results allowed to discern the term beobweon in the context of the names of court types (with simultaneous elimination of other phrases not constituting the names of courts, of which the said term forms a $\operatorname{part}^{17}$ ) in the following way:

1. 각급 법원 各級法院 kaggeub beobweon

2. 하급법원 下級法院 hageub beobweon

3. 고등법원 高等法院 godeung beobweon

4. 지방법원 地方法院 jibang beobweon

5. 대법 원 大法院 daebeobweon

6. 군사법원 軍事法院 gunsa beobweon

7. 특허법원 特許法院 teugheo beobweon

8. 가정법원 家庭法院 gajeong beobweon

9. 행정법원 行政法院 haengjeong beobweon

The South Korean judicial system is based on the three instance trial system. Therefore in this system such types as the high courts (term no. 3), district courts (term no. 4) and the Supreme Court (term no. 5) as the highest judicial body can be distinguished. As we can see, terms no. 1, 2 and 6 are of different range. Term no. 1 should be considered more as a phrase, as it means court of each level and refers more to the type and extent of authority, including instances than to the name of the judicial institution concerned. Similarly, the term number 2 refers to instance and means the court of lower instance. Term no. 6 applies to military court of a special use. Term no. 7 is used for patent court, which is also a court at the level of a high

\footnotetext{
16 Available at National Law Information Center database [41].

17 Such phrases eliminated from beobweon include, in Author's opinion, e.g. 법원 청사 beobweon cheongsa 'courthouse', 법원장 法院長 beobweon-jang 'court president' or 법원 직원 beobweon jigweon 'court employee'. The phrases were also containing apart from beobweon also the element jaepan as e.g. 법원 재판 beobweon jaepan 'court hearing'. One of the results of the dictionary search, i.e. 공평 한 법원 (公平한 法院) gongpyeonhan beobweon 'fair court' was also skipped.
} 
court, while term no. 8-family court and term no. 9-administrative court name courts at the level of district courts [42].

As we can see, in each of these terms and phrases word 법원 beobweon is used, as it was introduced in the previously mentioned Court Organizational Act. The above terms and phrases are all now in use. In case of North Korea, word 법원 beobweon is not in official use for court names.

\section{Conclusions}

The language of Korean law is particularly rich in the terminology of Chinese linguistic origin. The fact that the Chinese language was used as the official one, and thus historically was perceived superior to the Korean language for a very long time, speaks for that the analysis requires a knowledge of the Chinese characters semantics. Only such approach along with historical and language knowledge allows in-depth analysis of semantic arrangements. The lexical, contextual, historical and legal analysis of those two terms, usually explained with one hypernym term court allowed us to observe the differences at the hyponym level. The historical knowledge in the field of the judiciary and the language of law development was of enormous help.

The historical evidence clearly shows that both the Korean judiciary and officials performing judicial functions enjoyed great respect before Japan's annexation of Korea. Therefore, in the South Korean case, it seems more reasonable to use the term tribunal in historical contexts. The use of the term재판소 jaepanso is also noticeable in the case of contemporary terms referring to institutions of foreign origin or superior to other institutions. Therefore they may be perceived as not strictly South Korean in origin, but only as an adaptation to the changing conditions of the judiciary. Also, using the word tribunal in these cases may give the better linguistic impression. Therefore the term 법 원 beobweon is the basis for naming contemporary South Korean institutions and the term court seems to be appropriate. However, the author suggests that in the case of North Korean terminology the English term 'tribunal' should be used to a greater extent. In this case not only the term in real use should be taken into account but also the political, historical and ideological background.

Judicial terminology in Korea, both South and North, is a very interesting field for linguistic analysis in a semantic context. It also speaks for the fact that in the decision as to the techniques used in translation, the context and historical background are extremely important. 
Open Access This article is licensed under a Creative Commons Attribution 4.0 International License, which permits use, sharing, adaptation, distribution and reproduction in any medium or format, as long as you give appropriate credit to the original author(s) and the source, provide a link to the Creative Commons licence, and indicate if changes were made. The images or other third party material in this article are included in the article's Creative Commons licence, unless indicated otherwise in a credit line to the material. If material is not included in the article's Creative Commons licence and your intended use is not permitted by statutory regulation or exceeds the permitted use, you will need to obtain permission directly from the copyright holder. To view a copy of this licence, visit http://creativecommons.org/licen ses/by/4.0/.

\section{References}

1. Klemensiewicz, Zenon. 1999. Historia języka polskiego [A History of Polish Language]. Warszawa: PWN.

2. Grzegorczykowa Renata. 2001. Wprowadzenie do semantyki językoznawczej [Introduction to linguistic semantics]. Warszawa: PWN.

3. Zajda, Andrzej. 2001. Studia $z$ historii polskiego stownictwa prawniczego $i$ frazeologii [Studies in the history of Polish legal vocabulary and phraseology]. Kraków: Wydawnictwo Uniwersytetu Jagiellońskiego.

4. Górski, Kazimierz. 1979. Semantyczne i gramatyczne właściwości terminów technicznych [Semantic and grammatical properties of technical terms]. Studia Rossica Posnaniensia 12: 177-186.

5. Sohn, Ho-Min. 1999. The Korean language. Cambridge: Cambridge University Press.

6. Lee, Iksop, and R.S. Ramsey. 2000. The Korean language. Albany: SUNY Press.

7. Sim Jaegi 심재기, Jo Hang Beom 조항범, Mun Geum Hyeon 문금현, No Myeong Hui 노명희, Lee SeonYeong 이선영. 2011. 국어 어휘론 개설 [Studies on Korean Lexicography]. 서울 Seoul: 지식과 교양 Jisig-gwa gyoyang.

8. Act on Revised Romanization of 2000 국어의 로마자 표기법 gugeo-ui romaja pyogi-beob, http:// www.law.go.kr/admRulInfoP.do?admRulSeq=3561. Accessed 10 Oct 2019.

9. Beckwith, Christopher I. 2004. Koguryo, the language of Japan's continental relatives: An introduction to the historical-comparative study of the Japanese Koguryoic languages with a preliminary description of archaic northeastern middle Chinese. Brill: Leiden-Boston.

10. Lee, Ki Moon, and Robert Ramsey. 2011. A history of Korean language. London: Cambridge University Press.

11. Seth, Michael J. 2010. A history of Korea: From antiquity to the present. Lanham: Rowman \& Littlefield Publishers.

12. Rurarz, Joanna P. 2005. Historia Korei [History of Korea]. Warszawa: Wydawnictwo DIALOG.

13. Naver Dictionary Online. https://ko.dict.naver.com/\#/entry/koko/e08458fc50484a36b8dc86173 8f170b4. Accessed 21 Feb 2020.

14. Wasilewska, H. 2019. Adaptacje i metamorfozy-znaki chińskie $w$ wybranych sinograficznych systemach Azji Wschodniej [Adaptations and metamorphoses: Chinese characters in selected sinographic scripts of East Asia]. Poznań: Wydawnictwo Poznańskiego Towarzystwa Przyjaciół Nauk.

15. Kyong-Geun, Oh. 2015. Ewolucja Języka Urzędowego w Korei [Evolution of Official Language in Korea]. Comparative Legilinguistics 22 (2015): 65-76.

16. Kim Kipyo. 2013. Overview. In: Introduction to Korean law, ed. Korea Legislation Research Institute. Springer: Berlin, pp. 1-30.

17. http://www.law.go.kr/법령/한글전용에 관한법률/(00006,19481009). Accessed 12 Sep 2019.

18. Naver Korean Language Dictionary Online. https://dict.naver.com/. Accessed 08 Sep 2019.

19. Act on correct spelling and rules of standardization 국어 기본법 gugeo gibon-beob from 2001, last amended September 22, 2017, www.law.go.kr/ 법령/국어기본법. Accessed 10 Oct 2019.

20. Draft act on taking special measures to correlate the language of law of December 29, 2004 법률 한글화 위한 특별 조치 법안 beobryul hangeulhwa wihan teugbyeol- jochi-beoban, https://www. moleg.go.kr/board.es?mid=a10504000000\&bid=0010\&act=view\&list_no=43646\&nPage $=133$. Accessed 10 Oct 2019. 
21. Yu Yeong-Ik 유영익. 2000. 갑오경장 [Gabo Reforms]. In: 한국사 40. 청일전쟁과 갑오개혁 [Korean History 40. The Sino-Japanese War and the Gabo Reform]. Ed. 국사편찬위원회 National Institute of Korean History. 서울 Seoul: 탐구당문화사 Tamgudang Munhwasa, pp. 144-309.

22. National Archives of Korea. http://www.archives.go.kr/next/common/archivedata/render.do?fileP ath $=2 F 757046696 c 652 F 70616 c 67616 \mathrm{e} 2 \mathrm{~F} 32303138303232365 f 303030362 \mathrm{e} 706466$. Accessed 14 Aug 2019.

23. National Law Information Center in Archives: http://www.law.go.kr/LSW//lsInfoP.do?lsiSe $\mathrm{q}=5111 \&$ anc $\mathrm{Yd}=19490926 \&$ ancNo $=00051 \&$ efYd $=19490815 \& \mathrm{nwJoYnInfo}=\mathrm{N} \&$ efGub un $=\mathrm{Y} \& \mathrm{chrClsCd}=010202 \# 0000$. Accessed 6 Sep 2019.

24. National Law Information Center 국자법령정보센터. http://www.law.go.kr/LSW/lsTrmScLis tP.do? $\mathrm{q}=*$.\%3F\&outmax=50\&fsort=10. Accessed 09 Sep 2019.

25. 헌법재판소 Constitutional Court of Korea. https://www.ccourt.go.kr/cckhome/kor/main/index.do. Accessed 3 Sep 2019.

26. International Tribunal for the Law of the Sea. https://www.itlos.org/. Accessed 3 Sep 2019.

27. International Court of Justice. https://www.icj-cij.org/. Accessed 3 Sep 2019.

28. http://www.law.go.kr/법령/탄핵재판소법/(00304,19540123). Accessed 09 Sep 2019.

29. Korean Legal Terminology Dictionary 법률용어사전: http://www.law.go.kr/lsTrmScListP.do? $\mathrm{q}=\% \mathrm{ED} \% 96 \% 89 \% \mathrm{EC} \% \mathrm{~A} 0 \% 95 \% \mathrm{EC} \% 9 \mathrm{E} \% \mathrm{AC} \% \mathrm{ED} \% 8 \mathrm{C} \% 90 \% \mathrm{EC} \% 86 \% 8 \mathrm{C} \&$ outmax $=15 \&$ fsort =10\#AJAX. Accessed 8 Sep 2019.

30. http://www.law.go.kr/법령/특별재판소및특별검찰부조직법/(00567,19601230). Accessed $10 \mathrm{Sep}$ 2019.

31. http://www.law.go.kr/법령/혁명재판소및혁명검찰부조직법/(00690,19610824). Accessed 14 Sep 2019.

32. Democratic People's Republic of Korea Constitution, https://www.unilaw.go.kr/bbs/selectBoardArti cle.do. Accessed 21 Sep 2019.

33. Choi, C. (최종고) 2005. 北韓法의 歷史的 形成과 變化 북한법의 역사적 형성과 변화 (Bukhan beob-ui yeogsa-jeog hyeongseong-gwa byeonhwa) [Historical Development and Recent Changes of North Korean law]. 서울대학교 법학, 제 46 권 제 1호 [Seoul University Law Studies, 46 (1)], pp. $371-412$.

34. Lee, Gyu-Chang, and Gwang-Jin Jeong (이규창, 정광진). 2011. 북한형사재판제도: 특징과 실 태 Bukhan Hyeongsa Jaepan jedo: teugjing-gwa siltae [Study on the North Korean Criminal Trial System: Characteristics and Realities]. Seoul: Korean Institute for National Unification.

35. Yeon, Jaehoon. 2012. Korean dialects: a general survey. In The languages of Japan and Korea, ed. Nicholas Tranter, 168-185. Abingdon and New York: Routledge.

36. Korean Language Dictionary Online. https://ko.dict.naver.com/\#/entry/koko/293dc7a2347e432 b8d1468952dcd10b8. Accessed 14 Sep 2019.

37. Korean Language Dictionary Online. https://hanja.dict.naver.com/ word?q=\%E6\%B3\%95\%E6\%BA\%90\&cp_code=0\&sound_id=0. Accessed 14 Aug 2019.

38. Legal Terminology Dictionary 법령용어사전. http://www.law.go.kr/lsTrmScListP.do?q=\%EB\%B $2 \% 95 \% \mathrm{EC} \% 9 \mathrm{~B} \% 90$ (\%EB\%B2\%95\%EC\%9D\%98\% EC\%97\%B0\%EC\%9B\%90)\&outmax=15\&fsort =10. Accessed 09 Sep 2019 .

39. Legal Terminology Dictionary. http://www.law.go.kr/unSc.do?tabMenuId=tab84\&section=licNe wLsTrm\&query=\%EB\%B2\%95\%EC\%9B\%90\#AJAX. Accessed 09 Sep 2019.

40. Legal Definitions Dictionary. http://www.law.go.kr/LSW/unSc.do?tabMenuId=tab84\&secti on $=$ licNewLsTrm\&dicClsCd=011402\&query $=\% \mathrm{~EB} \% \mathrm{~B} 2 \% 95 \% \mathrm{EC} \% 9 \mathrm{~B} \% 90$. Accessed 08 Sep 2019.

41. National Law Information Center. http://www.law.go.kr/LSW/unSc.do?tabMenuId=tab300\&secti on=licLmst\&query=\%EB\%B2\%95\%EC\%9B\%90. Accessed 14 Sep 2019.

42. https://eng.scourt.go.kr/eng/judiciary/introduction.jsp. Accessed 28 Sep 2019.

Publisher's Note Springer Nature remains neutral with regard to jurisdictional claims in published maps and institutional affiliations. 